\title{
Pola Komunikasi Suku Samin Di Kabupaten Blora Terkait Ajaran Yang Dianutnya
}

\author{
Emillia Vinna Octaviani \\ (emilveoctiani@gmail.com) \\ (Alumni Ilmu Komunikasi FTIK USM)
}

\begin{abstract}
The aim of this study determines the communication pattern samin tribal culture to the community in Blora related teachings espoused, and know the pattern of tribal cultural communication to the outside community cumin cumin in Blora related teachings espoused .The theoretical basis of communication used the symbolic interactionism. This theory explains humans interact and exchange of meaning, create, send, receive symbol agreed. The method used is the in-depth interviews and observation. Researchers chose purposive sampling as a technique of sampling. The case study research in lakukasn in Samin tribe and the village of Sambong Klopoduwur District of Banjarejo.
\end{abstract}

Kata Kunci : Buku, Makna, Interaksionalisme Simbolik

\section{Pendahuluan}

Menurut herman ( $1994: 17$ ) dalam ajaran Samin yang disebarkan oleh Samin Suresentiko, Blora memilki kelompok masyarakat yang disebut dengan Orang Samin. Masyarakat tersebut merupakan masyarakat yang masih mengikuti ajaran-ajaran Samin. Ajaran Samin disebut juga pergerakan Samin atau Saminisme adalah salah satu suku yang ada di Indonesia.

Masyarakat ini adalah keturunan para pengikut Samin Surosentiko yang mengajarkan sedulur sikep, di mana merekamengobarkan semangat perlawanan terhadap Belanda dalam bentuk lain di luar kekerasan. Bentuk yang dilakukan adalah menolak membayar pajak, menolak segala peraturan yang dibuat pemerintah kolonial. Masyarakat ini acap memusingkan pemerintah belanda maupun penjajahan jepang karena sikap itu, sikap yang hingga sekarang dianggap menjengkelkan oleh kelompok di luarnya.

Masyarakat Samin sendiri juga mengisolasi diri hingga baru pada tahun 70-an, mereka baru tahu Indonesia telah merdeka. Kelompok Samin ini tersebar sampai Jawa Tengah, namun konsentrasi terbesarnya berada di kawasan Blora. Kelompok Samin lebih suka disebut wong sikep, karena kata samin bagi mereka mengandung makna negatif. Orang luar Samin sering menganggap mereka sebagai kelompok yang lugu, tidak suka mencuri, menolak membayar pajak, dan acap menjadi bahan lelucon.

Samin merupakan tokoh masyarakat yang sampai saat ini dijadikan sebagai salah satu tokoh yang memiliki jasa dalam pergerakan melawan penjajah dan penindasan pada masa-masa itu. Samin lahir di desa Ploso Kedhiren kecamatan Randublatung kabupaten Blora pada tahun 1859 (Suripan, 
1996:13). Ayahnya bernama Raden Surowijoyo, yang bekerja sebagai bormocorah, maksudnya bekerja untuk kepentingan orang-orang desa yang miskin dari daerah Bojonegoro Jawa Timur. Nama samin yang asli adalah Raden Kohar.Nama ini kemudian diubah menjadi Samin, yaitu sebuah nama yang bernapas kerakyatan.

Samin melihat langsung bagaimana keadaan dan kondisi orangorang miskin yang ada di wilayahnya (Randublatung dan sekitarnya), mulai dari tradisi, kehidupan sehari-hari, bahkan penindasan-penindasan yang dilakukan oleh pemerintahan pada waktu itu kepada masyarakat miskin tersebut. Diusianya yang menginjak dewasa, Samin sering menyendiri. Berdasarkan sejarah, Samin sering nyepi atau bertapa di hutan. Pada suatu hari ketika Samin nyepi di hutan, datang suara gaib atau wahyu. Suara gaib itu mengatakan kepadanya, bahwa di suatu tempat yang telah ditunjuk ada suatu buku yang berkhasiat. Adapun khasiat dari buku tersebut, barang siapa memiliki buku itu, akan menjadi manusia yang sempurna (Herman, 1994: 17).

Berdasarkan peristiwa itulah kemudian Samin menjadi orang sempurna (menurut ukuran ajaran orang Samin). Samin terus belajar dari buku yang telah dimilikinya, kemudian mengajarkannya kepada masyarakat disekitarnya, sehingga makin lama makin banyak pengikut ajaran Samin. Ajaran Samin ini juga dinamakan Sedulur Sikep.

Interaksi Simbolik Interaksionisme simbolik proses dimana dirisendiri dikembangkan. Interaksionisme simbolis merupakan sebuah pergerakan dalam sosiologi, berfokus pada cara - cara manusia membentuk makna dan susunan dalam bermasyarakat melalui percakapan misalnya, manusia memahami pengalaman mereka melalui makna dalam simbol dari kelompok utama mereka dan bahasa merupakan bagian penting dalam kehidupan sosial, tindakan manusia didasarkan pada penafsiran mereka

dimana objek dan tindakan yang berhubungan dalam situasi yang dipertimbangkan atau diartikan. (Tephen W.LittleJohn, 1996:231).

Interaksionisme simbolik juga sebagai sebuah gerakan, untuk meneliti cara - cara manusia berkomunikasi. individu tentang realitas yang dituntun oleh cerita-cerita yang menggambarkan bagaimana segala sesuatu diyakini ada( William B.Gudykunst, 2001:236)

Dalam teori interaksionisme simbolis yang menyangkut ajaran suku samin, ditandai oleh sikap dan perilaku atau perbuatan yang tidak selalu mengikuti adat istiadat dan aturan yang berlaku di desa atau masyarakat di mana mereka tinggal. Hal ini diawali oleh sikap diri sendiri yang mulai berani melawan kebijakan pemerintah kolonial belanda. Perlawanan tidak dilakukan dengan cara kekuatan fisik tetapi dengan menentang. Menurut Mead dalam Richard West (2009: 104-105) ada tiga konsep penting dalam teori interaksi simbolik. Tiga konsep penting menurut Mead adalah pikiran (mind), diri (self), dan masyarakat (society). Ketiga konsep dasar ini saling tumpang tindih hingga batasan tertentu, hal tersebut merupakan konsekuensi penggambaran sebuah teori dengan terminologi global yang dapat dilihat dengan berbagai cara.

Komunikasi Budaya Budaya berkenaan dengan cara manusia hidup. Manusia belajar berpikir, merasa, mempercayai, dan mengusahakan apa yang patut menurut budayanya. Apa yang orang lakukan, dan bagaimana mereka 
bertindak, bagaimana mereka hidup dan berkomunikasi, merupakan respon terhadap budaya mereka.

Seperti ajaran Suku Samin mereka hidup banyak membahas hubungan sosial kemasyarakatan. Hubungan sesama manusia atau masyarakat diajarkan dengan sebaik mungkin. Orang Samin mencintai hidup rukun dan gotong royong, tidak boleh ada warga yang bermusuhan, berselisih pendapat dengan cara - cara kasar. Segala persoalan dalam masyarakat dibicarakan dengan sebaik mungkin dan tidak boleh saling menang menangan.

Budaya komunikasi adalah Suatu konsep yang membangkitkan minat. Secara formal budaya didefinisikan sebagai tatanan pengetahuan, pengalaman, kepercayaan, nilai, sikap, makna, hirarki, agama, waktu, peranan, hubungan, ruang, konsep alam semesta, objek - objek materi dan milik yang diperoleh sekelompok besar orang dari generasi ke generasi kelompok dan individu( Deddy Mulyana, 2005: 18 ).

Bagi masyarakat Suku Samin, bertindak dusta merupakan hal yang sangat tabu. Mereka memegang prinsip kejujuran, berbicara apa adanya tidak muluk muluk dan memberikan keterangan keterangan yang sesuai dengan fakta yang ada.

Berdasarkan ilmu sosial orang Samin, memiliki prinsip yang sangat terpuji mengenai pandangan hidupnya. Orang sedulur sikep sangat menjunjung tinggi kejujuran, welas asih, persaudaraan, dan mencintai lingkungan hidup serta alam semesta. Dan realitasnya, hingga kini warga Samin saling menghormati dan kerukunan masyarakatnya memang tinggi, mereka biasa selalu saling membantu dalam keadaan apa pun.
Pembahasan

Dalam teori interaksionisme simbolik yang menyangkut ajaran suku samin, ditandai oleh sikap dan perilaku atau perbuatan yang tidak selalu mengikuti adat istiadat dan aturan yang berlaku di desa atau masyarakat di mana mereka tinggal.Hal ini diawali oleh sikap diri sendiri yang mulai berani melawan kebijakan pemerintah kolonial belanda.Perlawanan tidak dilakukan dengan cara kekuatan fisik tetapi dengan menentang. Tiga konsep penting dalam teori interaksi simbolik, adalah pikiran (mind), diri (self), dan masyarakat (society).

Konsep pertama pikiran (mind) adalah kemampuan manusia mengembangkan pikiran melalui interaksi dengan orang lain, seseoarng berinteraksi dengan orang lain menggunakan bahasa ( language ) diartikan untuk pola - pola mengekspresikan pemikiran dan perasaan yang dimiliki bersama.

Pola komunikasi Suku Samin sesama masyarakat Samin berjalan dengan baik. Mereka samin tidak mengalami kesulitan ataupun kendala dalam melakukan interaksi sosial.Apabila ada warga Samin yang memiliki kerja, Mantenan misalnya, warga Samin yang ada disekitar saling membantu, beigtu juga sebaliknya. Mereka memiliki adat tersendiri dalam melakukan Kerja. Dalam kehidupan sehari-hari suku Samin menggunakan bahasa jawa ngoko kasar disertai perumpaan. Dalam betutur kata mereka selaku mengedepankan pada sifat kejujuran dan melarang untuk berbuat bohong, mencuri, dan berzina. Dalam kehidupan di masyarakat sifat inilah yang memang perlu di dilaksanakan dan dijaga dengan baik. 


\section{Kesimpulan}

$\underset{\text { diterapkan danan }}{\text { Suku Samin yang }}$ lingkungan di sekitar Samin, masyarakat di daerah Suku Samin menggunakan bahasa jawa ngoko kasar dalam kehidupan sehari - hari dan tidak boleh bermusuhan, berselisihan terhadap sesama masyarakat Suku Samin. Ajaran Suku Samin banyak membahas tentang hubungan sosial kemasyarakatan misalnya, sesama orang samin mencintai hidup rukun, senantiasa menepati janji, dan saling bergotong royong yang dilakukan dengan iklas tanpa mengharap kan upah atau gaji.

Meski Suku Samin telah hidup di era modern tapi warga Suku Samin masih memegang teguh tentang ajaran - ajaran samin, yang mencakup tentang tidak dibolehkannya seoseorang untuk bersekolah. Demikian pula tata cara berpakaian masyarakat Suku Samin terlihat memakai pakaian serba hitam dan tidak memakai sandal.

sebaliknya masyarakat Suku Samin tidak suka mengggangu atau mengatur kehidupan masyarakat luar Samin. Rasa saling menghormati satu sama lain dan kerukunan masyarakat Samin terhadap masyarakat luar terjalin baik.

\section{Daftar Pustaka}

Arikunto,Suharsimi.2002.ProsedurPeneli tian Suatu Pendekatan Praktek. Jakarta: RinekaCipta

Andi Setiono. 2011. EnsiklopediBlora, Buku 10. Yogyakarta: PT. NuansaPilar Media

Herman.1994. Menuju Dalam Perjalanan, Sejarah Perjuangan Kemerdekaan Di Kabupaten Blora. Blora: Dewan Harian Cabang Angkatan 45 Kabupaten Blora.

Hamidi,Metode Penelitian dan Teori Komunikasi, (Malang: UMm Press, 2007), hlm. 124

Lexi J. Moleong. 2007.Metode Penelitian Kualitatif. Bandung: Remaja Rosdakarya.

Roudlotul,Siti.2009. Akulturasi Budaya Ajaran Samin Surosentiko dan Islam di Desa blimbing Kecamatan Sambong Kabupaten Blora. Yogyakarta: UIN Sunan Kalijaga Yogyakarta.

Maulana. Ahmad 2013. Mobilitas Sosial Masyarakat Samin. http://sekitaraku94.blogspot.com. Diakses padatanggal 20 juni 2013

Purnomo, Wisnu 2013 . SejarahSaminwongsamins.http://wongsamins.wee bly.com. Diakses Pada tanggal 10 maret 2015.

Sastroatmodjo, Suryanto, 1952. Masyarakat Samin Blora, Jakarta: Penerbit Central java Jawa Jakarta. 